\title{
Selection Criteria and Selection Environment for Drought Tolerance of Egyptian Wheat (Triticum aestivum L.) Landraces
}

\author{
Ahmed Medhat Mohamed Al-Naggar ${ }^{1^{*}}$, Mohamed Abd El-Maboud Abd El-Shafi, \\ Mohamed Helmy El-Shal ${ }^{2}$ and Ali Hassan Anany ${ }^{2}$ \\ ${ }^{1}$ Department of Agronomy, Faculty of Agriculture, Cairo University, Giza, Egypt. \\ ${ }^{2}$ National Gene Bank, Agricultural Research Centre, Giza, Egypt.
}

\begin{abstract}
Authors' contributions
This work was carried out in collaboration among all authors. Author AMMAN designed the study, wrote the protocol and wrote the first draft of the manuscript. Authors MAEMAES and MHES managed the literature searches. Author AHA managed the experimental process and performed the data analyses. All authors read and approved the final manuscript.

Article Information

DOI: $10.9734 / A R R B / 2020 / v 35 i 230186$

Editor(s):

(1) Bechan Sharma, University of Allahabad, India. Reviewers:

(1) Aba-Toumnou Lucie, University of Bangui, Central African Republic.

(2) Husnu Aktas, Mardin Artuklu University, Turkey.

(3) Miroslava Rakocevic, UNICAMP, Brazil.

Complete Peer Review History: http://www.sdiarticle4.com/review-history/55937
\end{abstract}

Original Research Article

Received 27 January 2020

Accepted 02 April 2020

Published 08 April 2020

\section{ABSTRACT}

Strong correlations between wheat traits and drought tolerance (DT) associated with high heritability and high genetic advance from selection would allow plant breeder to use such traits as selection criteria. The objective of the present investigation was to determine the optimum selection criteria and selection environment for drought tolerance via estimation of correlation coefficients $(r)$ among 13 agronomic, grain yield and quality traits and DT of 20 wheat landraces, broad-sense heritability $\left(\mathrm{h}_{\mathrm{b}}^{2}\right)$ and genetic advance $(\mathrm{GA})$ from selection for such traits under well-watered (WW) and water stressed (WS) environments. A two-year experiment was carried out using a split-plot design with four replications. Results concluded that the best selection criterion for drought tolerance in our study was grain yield/plant (GYPP), followed by a number of grains/spike (GPS), grain filling period (GFP), grain starch (GSC) and protein (GPC) content, plant height $(\mathrm{PH})$ and days to maturity (DTM), since they showed high $(r)$, high $h_{b}^{2}$ and high GA estimates. The best 
selection environment was WW for days to anthesis, $\mathrm{PH}$, spikes/plant, GPS, spikelets/spike, GYPP, GPC and WS for DTM, GFP, GSC and thousand-grain weight traits. This information could help future breeding programs in selection for improving drought tolerance of wheat.

Keywords: Deficit irrigation; trait correlations; heritability; genetic advance; genetic variability.

\section{INTRODUCTION}

Wheat (Triticum aestivum L.) is an important and strategic cereal crop for the majority of world populations [1]. Wheat is mainly used as a staple food providing more than $20 \%$ of calories and protein for human nutrition for over $35 \%$ of the world's population in more than 40 countries. Wheat is the most widely grown cereal grain, occupying 17 percent of the total cultivated land in the world, which accounts for 21.8 percent of the total area under food grains [2].

In Egypt, the wheat harvested area in 2017 is $1,342,805$ ha, the annual consumption of wheat grains is about 19 million tons, while the local production is about 8.8 million tons with average grain yield of $6.55 \mathrm{t} / \mathrm{ha}$ [3]. Therefore, the gap between annual local production and consumption is about 10.2 million tons, which is imported from Russia, Australia, France, etc. Egypt is trying to narrow this gap by increasing the local production of wheat in two ways [4]. The first way is through vertical expansion, i.e. increasing wheat production per unit area through the development of new cultivars of high yielding ability, resistance to biotic and abiotic stresses, and the adoption of recommended cultural practices for growing these cultivars. The second way is through horizontal expansion, i.e. by increasing the area cultivated with wheat. Horizontal expansion in Egypt is available only in the desert, where the soil is of low water holding capacity and thus needs improved wheat cultivars to tolerate drought stress, which could result in obtaining low grain yields under such conditions [4]. Moreover, the expected future shortage in irrigation water necessitates that wheat breeders should pay great attention to develop drought-tolerant wheat cultivars that could give high grain yield under water-stress conditions. In the last decades, a yield plateau of wheat was reported in Egypt and many European countries [5]. However, a significant increase in wheat yield will be required if demand from the growing human population, is to be met. The challenge for wheat breeders is to increase the rate of genetic gain in yield at a rate not lower than the rate of growing human population.
To increase the genetic progress in yield, wheat breeders search for germplasm of high genetic diversity, one of them is the landraces. A wheat landrace is defined by Zeven [6] as a traditional variety with good tolerance to biotic and abiotic stresses. It has high stability but shows moderate yield under a poor environment. It is generally thought that during the process of wheat domestication, new adaptive traits suitable for the new environments were selected [7]. Probably traits such as easy harvest, large seeds, nonshattering plants were considered as the main aims of the ancient farmers [8], or flowering time to fit with the prevailing environmental conditions of the region [9]. Many other characteristics had also been selected by farmers, such as plant height, number, and weight of spikes and grains [7]. Wheat landraces cultivated in the Saharan oases that have been subjected during centuries to drought, heat, and salinity are expected to have developed tolerance to these stresses; most landraces may have been introduced from Egypt, possibly during wet climatic episodes [10].

The estimation of the heritability is a very useful parameter for breeders because it allows one to predict the possibility of success with the selection, as it reflects the proportion of phenotypic variation that can be inherited; in other words, the heritability coefficient measures the reliability of the phenotypic value as an indicator of genotypic value [11]. Heritability estimates facilitate the choice of methods and characters used in the initial and advanced phases of improvement programs, thereby allowing the study of mechanisms, genetic values and variability for one character [12]. The estimations of high coefficients of heritability are associated with greater genetic variability, greater selective accuracy [13] and greater possibilities for success in selecting genotypes with higher productivity of grain [4].

Because of the low efficiency of selection for a quantitative character like grain yield particularly under stress environments, wheat breeders need to identify alternative selection criteria, which may have a strong association with yield, have high heritability and can be measured accurately in a 
large population [14]. Grain yield of wheat is negatively associated with days to heading [15], while Golabady and Arzani [16] find that grain yield shows a positive and significant correlation with days to heading and days to maturity. Moreover, grain yield shows highly significant and positive correlations with plant height, number of spikes/plant, number of kernels/spike and 100kernel mass under both water stress and nonstress conditions [15]. Grain yield/plant is genetically correlated with the number of spikes/plant in all studied crosses under both stress and non-stress conditions [17]. This indicates that spikes/plant is important for the selection of plants with high tolerance to drought and is therefore considered as a good selection criterion for high yield under water stress, especially if it showed high heritability under both stress and non-stress conditions [4]. The importance of spikes/plant in addition to grain yield as selection criteria for drought tolerance in wheat was also reported by other breeders [18]. A number of grains per spike, thousand-grain mass and a number of fertile tillers are the most effective components of grain yield, indicating that these traits could be used as important indices for high yielding bread wheat genotypes selection [19].

There is a need to assess the heritability of agronomic traits as a prerequisite for developing cultivars with enhanced drought tolerance in wheat which is increasingly being grown under drier conditions due to global warming. However, the lack of adequate information on the heritability and correlations between yield-related traits and drought tolerance limits the development of ideotypes with suitable criteria for drought tolerance [4]. Thus, the objectives of the present investigation were to estimate: (i) the phenotypic and genotypic coefficients of variation and correlation coefficients among 13 traits of 20 landraces and two check varieties under normal and deficit irrigation and (ii) the heritability and genetic advance from selection in order to determine the optimum selection environment and selection criteria for improving drought tolerance and grain yield of wheat.

\section{MATERIALS AND METHODS}

\subsection{Plant Materials}

Seeds of 20 bread wheat (Triticum aestivum L.) Egyptian landraces, obtained from the National Gene Bank, Agricultural Research Center, (ARC), Egypt along with two checks, namely Sakha 64 (an Egyptian cultivar) and Yakora
Kogo (drought-tolerant variety) obtained from CIMMYT (Table 5) were used in the present investigation.

\subsection{Experimental Procedure}

The present investigation was carried out in the field of the experimental research station of ARC at Gemmieza (Gharbia Governorate) during the two seasons 2015/2016 and 2016/2017. The station is located at Gemmeiza $\left(30^{\circ} 48^{\prime \prime} \mathrm{N}, 31^{\circ}\right.$ 7' $30^{\prime \prime} \mathrm{E}$ and Altitude $=12 \mathrm{~m}$ above sea (evel). Sowing dates were at November $21^{\text {st }}$ and the $27^{\text {th }}$ in the first and second season, respectively.

A split-plot design in randomized complete block (RCB)s arrangement was used with four replications. Main plots were devoted to two irrigation regimes, i.e. normal irrigation by giving the recommended number (five) of irrigations (sowing irrigation, the second one after 21 days and the next ones after each 25 days) and deficit irrigation by giving only two irrigations (sowing irrigation and the next one after 21 days) after which irrigation was stopped till the end of the season. A border of $30 \mathrm{~m}$ width was done between the two main plots, besides digging a canal in the middle of this border of a $5 \mathrm{~m}$ width and $1 \mathrm{~m}$ depth [4]. The purpose of making this border was to prevent water interference from the full-irrigated main plot to the stressed one. Moreover, the whole experiment was isolated by a border of at least $14 \mathrm{~m}$ width far away from any source of irrigation water. Sub-plots were devoted to 22 wheat genotypes (20 Egyptian landraces and two check varieties).

The seeds were sown in individual hills in rows. Each row length was 2.5 meter and row to row distance was $20 \mathrm{~cm}$ and hill to hill distance was $20 \mathrm{~cm}$ (plot size was $3.0 \mathrm{~m}^{2}$ ). The fertilization was applied as recommended for commercial production by $\mathrm{ARC}$, using $35 \mathrm{~kg} \mathrm{P}_{2} \mathrm{O}_{5}(238 \mathrm{~kg}$ Mono-Super Phosphate 15.5\%) + $180 \mathrm{~kg}$ Nitrogen (535 kg Ammonium Nitrate 33.5\%) for hectare split in three times, first $20 \%$ with seeds, second $40 \%$ with first irrigation and third time $40 \%$ with second irrigation. Weeds, aphids, and diseases were controlled when needed according to the recommendations of the ARC. The soil of the experimental site was clayey with $\mathrm{pH}$ of 7.81 and $\mathrm{EC}$ was $4.90 \mathrm{dSm}^{-1}$.

\subsection{Data Recorded}

1. Days to anthesis (DTA).

2. Days to maturity (DTM).

3. Grain filling period (GFP).

4. Plant height $(\mathrm{PH})$. 
5. Number of spikes/plant (SPP)

6. Number of spikelets/spike (SPS).

7. Number of grains/spike (GPS).

8. Thousand-grain weight (TGW).

9. Grain yield/plant (GYPP).

10. Grain protein content (GPC).

11. Grain starch content (GSC).

12. Grain ash content (GAC).

13. Grain moisture content (GMC).

The grain quality traits (GPC, GSC, GAC and $\mathrm{GMC}$ ) were measured on samples taken from the grain bulk of each wheat genotype by using INSTALAB 600 Near Infrared (NIR) Product Analyzer manufactured by DICKEY-john Corporation, Auburn, Illinois, USA.

\subsection{Drought Tolerance Index (DTI)}

Drought tolerance index; the factor used to differentiate between the genotypes from the tolerance point of view was calculated following the equation suggested by Fageria [20]:

$\mathrm{DTI}=(\mathrm{Y} 1 / \mathrm{AY} 1) \times(\mathrm{Y} 2 / \mathrm{AY} 2)$

Where $\mathrm{Y} 1=$ mean grain yield of a genotype at well watering, $A Y 1=$ mean grain yield of all genotypes at well watering, $\mathrm{Y} 2=$ mean grain yield of a genotype at water stress, AY2 = mean grain yield of all genotypes at water stress. When DTI is $\geq 1.0$, it indicates that genotype is drought tolerant (DT), DTI is 1.0 , it indicates that genotype is moderately tolerant (MT), while $\mathrm{DTl}<1$, it indicates that genotype is drought sensitive (DS).

\subsection{Biometrical and Genetic Analyses}

Analysis of variance of the split-plot design in an RCB arrangement was performed on the basis of individual plot observation using the MIXED procedure of MSTAT ${ }^{\circledR}$. Combined analysis of variance of the split-plot across the two growing seasons was also performed if the homogeneity test was non-significant according to Steel et al.
[21]. Moreover, combined analysis of variance of randomized complete block design was performed for each environment; separately and combined across seasons. Least significant differences (LSD) were computed to compare means [4]. Phenotypic correlation coefficients (Spearman) among studied traits and their significance were calculated according to [21] by using SPSS 20 computer software.

The following equations were used to estimate genotypic (GCV) and phenotypic (PCV) coefficients of variations: GCV $=\left(\sigma_{g} / \bar{x}\right) \times 100$, PCV $=\left(\sigma_{p h} / \bar{x}\right) \times 100$, where: $\bar{x}=$ mean of the trait at the same irrigation regime.

Expected mean squares combined across seasons were estimated from the ANOVA table of RCB design (Table 1) according to Hallauer and Miranda [22].

Genotypic $\left(\sigma_{g}^{2}\right)$, phenotypic $\left(\sigma^{2}{ }_{p h}\right)$, genotype $x$ season $\left(\sigma_{g s}^{2}\right)$ and error $\left(\sigma_{e}^{2}\right)$ variances were computed as follows:

$\delta_{g e}^{2}=\left(M_{2}-M_{1}\right) / r$,

$\sigma_{g}^{2}=\left(M_{2}-M_{1}\right) / r$ (for one season),

$\sigma_{g}^{2}=\left(M_{3}-M_{2}\right) / s r$ (across seasons)

$\sigma_{p h}^{2}=\sigma_{g}^{2}+\left(\sigma_{e}^{2} / r\right)$. (for one season),

$\sigma^{2}{ }_{p h}=\sigma_{g}^{2}+\sigma_{g s}^{2} / r+\left(\sigma_{e}^{2} / r s\right)$. (across seasons)

where $r=$ number of replications, $g=$ number of genotypes and $s=$ number of seasons.

\subsection{Heritability in the Broad Sense}

Heritability in the broad sense $\left(\mathrm{h}_{\mathrm{b}}^{2} \%\right)$ for a trait in a separate environment was estimated according to [23] using the following formula:

$\mathrm{h}_{\mathrm{b}}^{2} \%=100 \times\left(\sigma_{\mathrm{g}}^{2} / \delta_{\mathrm{ph}}^{2}\right)$

where: $\sigma^{2}=$ genetic variance, and $\delta^{2}{ }_{p h}=$ phenotypic variance.

Table 1. Analysis of variance and expected mean squares (EMS) across seasons

\begin{tabular}{|c|c|c|c|}
\hline SV & df & MS & EMS \\
\hline \multicolumn{4}{|l|}{ For one season } \\
\hline Replication & 3 & & \\
\hline Genotype & 21 & M2 & $\delta^{2}{ }_{e}+r \delta^{2}{ }_{g}$ \\
\hline error & 63 & M1 & $\delta_{e}^{2}$ \\
\hline \multicolumn{4}{|l|}{ Across seasons } \\
\hline Season & 1 & - & - \\
\hline $\mathbf{R}(\mathbf{S})$ & 8 & - & - \\
\hline Genotype (G) & 21 & $M_{3}$ & $\delta_{e}^{2}+r \delta_{g s}^{2}+r s \delta_{g}^{2}$ \\
\hline $\mathbf{G} \times \mathbf{S}$ & 21 & $M_{2}$ & $\delta^{2}{ }_{e}^{2}+r \delta_{g s}^{20}$ \\
\hline Error & 84 & $\mathrm{M}_{1}$ & $\delta_{e}^{2}$ \\
\hline
\end{tabular}




\subsection{Expected Genetic Advance from the Selection}

Expected genetic advance from selection for all studied traits as a percent of the mean was calculated according to Singh and Narayanan [23] as follows: $\mathrm{GA}(\%)=\left(100 \mathrm{~K} \mathrm{~h}_{\mathrm{b}}{ }_{\mathrm{b}} \sigma_{\mathrm{ph}}\right) / \overline{\mathrm{x}}$, where: $\bar{x}=$ general mean, $\sigma_{\mathrm{ph}}=$ square root of the denominator of the appropriate heritability, $\mathrm{h}_{\mathrm{b}}^{2}=$ the applied heritability, $\mathrm{K}=$ selection differential $(\mathrm{K}=1.76$, for $10 \%$ selection intensity, used in this study).

\subsection{Trait Interrelationships}

Coefficients of Pearson (simple) correlations between attributes and their significance were calculated according to Steel et al. [21] by using SPSS 20 computer software.

\section{RESULTS AND DISCUSSION}

\subsection{Analysis of Variance}

Mean squares (Table 2) due to genotypes from analysis of variance of split-plot design across two years were significant, indicating significant differences among bread wheat genotypes (landraces and cultivars)for all studied traits. The coefficient of variation (CV) was very low (ranging from 0.99 to $10.89 \%$ ), indicating good accuracy of the experiment.

The range of grain yield/plant was between 14.12 to $20.48 \mathrm{~g}$ (Table 2). The Egyptian cultivar Sakha 64 (G22) had the highest grainyield, was the earliest genotype in maturity and had the highest number of grains/spike. Genotype G6 (Accession No. 9311) had the longest grain filling period, the highest number of spikes/plant, but was the latest genotype in maturity.

The landrace G17 (Accession No. 9150) had the highest grain protein content $(19.87 \%)$ but has the lowest grain yield/plant (14.12 $\left.\mathrm{g} \mathrm{plant}^{-1}\right)$ (Table 2). The protein content of the bread wheat landrace G17 was superior to that of modern cultivars. This can be explained that not only some agronomically important traits but also grain quality traits that have been decreased during term breeding of modern cultivars [24,25]. The landrace G17 can, therefore, be exploited in plant breeding programs for improving the grain protein content of the new bread wheat varieties. Our study recommends that landrace G17 could be crossed to one of the highest yielding genotypes (G22; Sakha 64, G2; Accession No. 9227 or G3; Accession No. 9234) to select in their segregating generations some transgressive segregants that accumulate genes of high grain yield and high grain protein content. The tallest plant characterized the landrace G11 (Accession No. 9120), but the shortest genotype was the landrace G2 (Accession No. 9227), which had the highest starch content. The genotype G18 (Accession No. 9293) was the earliest in anthesis. G14 had the highest grain moisture content.

Landraces no. 18, 6, 2, 6, 8, 14, 17 and 2 were shown as good sources of genes for earliness of anthesis, long grain filling period, short plant, large number of spikes/plant, large number of spikelets/spike, heavy thousand-grain weight, high protein content, and high starch content, respectively, since they showed the most favorable means in this experiment (Table 3). The landrace G2 (Accession No. 9227) had the highest grain yield amongst the studied 20 landraces (19.84 $\mathrm{g} \mathrm{plant}^{-1}$ ), with no significant difference as compared to that of Sakha 64 cultivar (20.43 $\mathrm{g} \mathrm{plant}^{-1}$ ). They could be offered to wheat breeders to use them in future breeding programs. Thus, landraces can be considered as likely sources of putatively lost variability and may provide new genes or alleles, which could be introgressed into modern varieties by hybridization [26].

Analysis of variance of RCBD across seasons (Table 3) for agronomic and yield traits under each environment separately (well-watered-WW or water stress-WS) showed that mean squares due to seasons were significant $(P \leq 0.05$ or $P \leq$ $0.01)$ for all studied traits under both WW and WS, except for spikelets/spike (SPS) under WS, assuring that the effect of season on the majority of traits was significant under each of studied environments due to the change of climatic conditions from one season to another. Mean squares due to genotypes were significant ( $P \leq$ 0.01 ) in both environments for all studied traits, except for grains/spike (GPS) under WS, indicating significant differences among all studied genotypes of wheat either under WW or under WS for the majority of cases. The variability among wheat landraces and varieties under water stress conditions is a prerequisite for initiating a successful breeding program for improving drought tolerance of this crop [10]. 
Table 2. Summary statistics for 13 phenotypic attributes of 22 wheat genotypes evaluated in the field across two irrigation regimes and two seasons

\begin{tabular}{|c|c|c|c|c|c|c|}
\hline Trait & Mean & Minimum & Maximum & $\begin{array}{l}\text { LSD }_{05} \\
\text { (Genotypes) }\end{array}$ & CV\% & $\begin{array}{l}\text { MS } \\
\text { (Genotypes) }\end{array}$ \\
\hline Days to Anthesis (day) & 109.3 & $\begin{array}{l}108.26 \\
(\mathrm{G} 18)\end{array}$ & $\begin{array}{l}110.8 \\
(G 2)\end{array}$ & 0.88 & 1.01 & ** \\
\hline Days to maturity (day) & 149.19 & $\begin{array}{l}140.0 \\
\text { (G22) }\end{array}$ & $\begin{array}{l}155.3 \\
(\mathrm{G} 6)\end{array}$ & 1.24 & 1.04 & ** \\
\hline Grain filling period (day) & 39.69 & $\begin{array}{l}30.53 \\
(G 22)\end{array}$ & $\begin{array}{l}44.79 \\
(\mathrm{G} 6)\end{array}$ & 1.47 & 4.60 & ** \\
\hline Plant height $(\mathrm{cm})$ & 120.5 & $\begin{array}{l}100.7 \\
(G 2)\end{array}$ & $\begin{array}{l}129.6 \\
\text { (G11) }\end{array}$ & 3.03 & 3.12 & ** \\
\hline Spikes/plant & 8.96 & $\begin{array}{l}8.42 \\
(G 22)\end{array}$ & $\begin{array}{l}9.59 \\
(\mathrm{G} 6)\end{array}$ & 0.36 & 5.05 & ** \\
\hline Grains/spike & 50.30 & $\begin{array}{l}44.2 \\
\text { (G3) }\end{array}$ & $\begin{array}{l}56.5 \\
(\mathrm{G} 22)\end{array}$ & 4.41 & 10.89 & ** \\
\hline Spikelets/spike & 10.97 & $\begin{array}{l}10.24 \\
\text { (G18) }\end{array}$ & $\begin{array}{l}11.77 \\
(\mathrm{G} 8)\end{array}$ & 0.55 & 6.23 & $* *$ \\
\hline 1000-Grain weight (g) & 48.23 & $\begin{array}{l}40.88 \\
\text { (G17) }\end{array}$ & $\begin{array}{l}51.88 \\
\text { (G14) }\end{array}$ & 2.12 & 5.47 & ** \\
\hline Grain yield/plant (g) & 16.15 & $\begin{array}{l}14.12 \\
\text { (G17) }\end{array}$ & $\begin{array}{l}20.48 \\
(G 22)\end{array}$ & 1.19 & 9.16 & $* *$ \\
\hline Moisture Content \% & 13.05 & $\begin{array}{l}11.93 \\
\text { (G11) }\end{array}$ & $\begin{array}{l}13.87 \\
\text { (G14) }\end{array}$ & 0.32 & 1.50 & ** \\
\hline Protein Content \% & 14.30 & $\begin{array}{l}10.54 \\
(G 2,4)\end{array}$ & $\begin{array}{l}19.87 \\
\text { (G17) }\end{array}$ & 0.42 & 1.80 & ** \\
\hline Starch Content \% & 62.65 & $\begin{array}{l}56.23 \\
\text { (G17) }\end{array}$ & $\begin{array}{l}67.97 \\
\text { (G2) }\end{array}$ & 1.01 & 0.99 & ** \\
\hline Ash Content \% & 1.78 & $\begin{array}{l}1.14 \\
(\mathrm{G} 21)\end{array}$ & $\begin{array}{l}3.16 \\
\text { (G17) }\end{array}$ & 0.22 & 7.55 & ** \\
\hline
\end{tabular}

Mean squares due to all interactions were significant ( $P \leq 0.05$ or $P \leq 0.01$ ) for all studied traits under WW or WS, except $G \times S$ for days to anthesis (DTA) under WW and grains/spike (GPS) under WS, indicated the differential response of genotypes for the majority of studied traits from one season to another under a specific irrigation regime (Table 3 ).

Several studies have indicated that there is a genotypic variation in grain yield of bread wheat under water stress and non-stress conditions [18]. Several workers also reported genotypic differences in wheat under both drought stress and non-stress conditions for number of spikes/plant [27,28], grains per spike [29], 100-grain mass [27,30] and plant height [18,29,31].

Analysis of variance of RCBD for grain quality traits (Table 4) under each environment separately (WW or WS) tested for one season (2016/2017), showed that mean squares due to
22 genotypes were significant $(P \leq 0.01)$ for all studied grain composition traits under both environments, except for GMC under WS, indicating the existence of genotypic differences among landraces and cultivars under WW and WS for GPC, GSC, GAC and under WW for GMC.

Several investigators reported genotypic variation in grain protein content in wheat [3234]. Changes in protein content with the application of different irrigation levels differ with cultivar $[35,36]$. Semidwarf wheat cultivars show a smaller increase in grain protein with small applications of $\mathrm{N}$ fertilizer than do cultivars of conventional height due to greater yield potential of semidwarf wheat [35]. The rank of wheat genotypes for GPC, GSC, GMC, and CAC was similar in the two environments, indicating less effect of interaction between genotype and irrigation level on these traits. A similar conclusion for GPC was reported by Al-Naggar et al. [33]. 
Generally, it is known that drought-induced reduction in crop grain yield is associated with an increase in protein content [37]. A study carried out in several regions of Spain showed moisture stress caused by low rainfall resulted in a significant increase in protein content in the grains of durum wheat [38]. Another study [39] in southern Spain showed maximum values of protein content during the period when rainfall was lowest. Drought stress is known to reduce the contents of carbohydrates including sucrose and starch in cereal grains, the latter being $65 \%$ of cereal kernels [40].

\subsection{Drought Tolerance Index}

Drought tolerance index (DTI) values of studied genotypes estimated using the equation suggested by Fageria [20] under WS are presented in Table 5 and Fig. 1.

Based on DTI values, the 22 studied wheat genotypes were grouped into three categories under water stress, namely tolerant (9 genotypes; 7 landraces and the two checks), moderately tolerant (one genotype; the landrace G14) and sensitive (12 landraces).

Table 3. Combined analysis of variance of RCBD design for agronomic and yield traits of 22 wheat landraces and varieties evaluated under well watering (WW) and water stress (WS) across two seasons

\begin{tabular}{|c|c|c|c|c|c|c|c|}
\hline \multirow[t]{3}{*}{ SV } & \multirow[t]{3}{*}{ Df } & \multicolumn{6}{|c|}{ Mean squares } \\
\hline & & WW & WS & WW & WS & WW & WS \\
\hline & & \multicolumn{2}{|c|}{ DTA } & \multicolumn{2}{|c|}{ DTM } & \multicolumn{2}{|c|}{ GFP } \\
\hline Seasons(S) & 1 & $869.9^{* *}$ & $1631.1^{* *}$ & $3393.4^{* *}$ & $176.69^{*}$ & $7957.4^{* *}$ & 3143.** \\
\hline Error & 4 & 5.611 & 8.973 & 6.302 & 11.41 & 9.903 & 13.05 \\
\hline Genotype (G) & 21 & $8.98^{\star *}$ & $2.21^{*}$ & $77.19^{* *}$ & $73.39^{\star *}$ & $63.20^{* *}$ & $68.26^{\star *}$ \\
\hline G x S & 21 & $1.57 \mathrm{~ns}$ & $2.134^{*}$ & $35.34^{* *}$ & $72.18^{* *}$ & $34.95^{\star *}$ & $67.51^{* *}$ \\
\hline \multirow[t]{2}{*}{ Error } & 84 & 1.332 & 1.107 & 3.85 & 0.919 & 4.597 & 2.074 \\
\hline & & \multicolumn{2}{|c|}{ PH } & \multicolumn{2}{|c|}{ SPP } & \multicolumn{2}{|c|}{ GPS } \\
\hline Seasons(S) & 1 & $958.72^{\star *}$ & $770.05^{*}$ & $5.683^{*}$ & $39.85^{\star \star}$ & $2168.05^{\star \star}$ & $6749.6^{* *}$ \\
\hline Error & 4 & 6.093 & 49.238 & 0.47 & 0.202 & 19.945 & 44.178 \\
\hline Genotype (G) & 21 & $393.35^{\star *}$ & $281.61^{* *}$ & $1.417^{* *}$ & $1.093^{* *}$ & $152.98^{* *}$ & $57.37 \mathrm{~ns}$ \\
\hline $\mathbf{G} \times \mathbf{S}$ & 21 & $418.27^{* *}$ & $291.53^{* *}$ & $0.685^{* *}$ & $1.057^{* *}$ & $73.01^{* *}$ & $59.78 n s$ \\
\hline \multirow[t]{2}{*}{ Error } & 84 & 19.446 & 8.845 & 0.281 & 0.128 & 18.016 & 42.017 \\
\hline & & \multicolumn{2}{|c|}{ SPS } & \multicolumn{2}{|c|}{ TGW } & \multicolumn{2}{|c|}{ GYPP } \\
\hline Seasons(S) & 1 & $4.723^{*}$ & $2.360 \mathrm{~ns}$ & $118.71^{* *}$ & $680.95^{\star *}$ & $42.35^{\star \star}$ & $1391.58^{\star *}$ \\
\hline Error & 4 & 0.564 & 0.486 & 5.33 & 2.392 & 1.835 & 5.076 \\
\hline Genotype (G) & 21 & $2.016^{* *}$ & $1.148^{* *}$ & $51.129^{* *}$ & $48.83^{* *}$ & $27.19^{* *}$ & $18.46^{* *}$ \\
\hline G x S & 21 & $1.202^{*}$ & $1.158^{* *}$ & $46.43^{* *}$ & $49.22^{* *}$ & $21.35^{\star *}$ & $18.71^{* *}$ \\
\hline Error & 84 & 0.665 & 0.269 & 11.84 & 2.088 & 2.847 & 1.528 \\
\hline
\end{tabular}

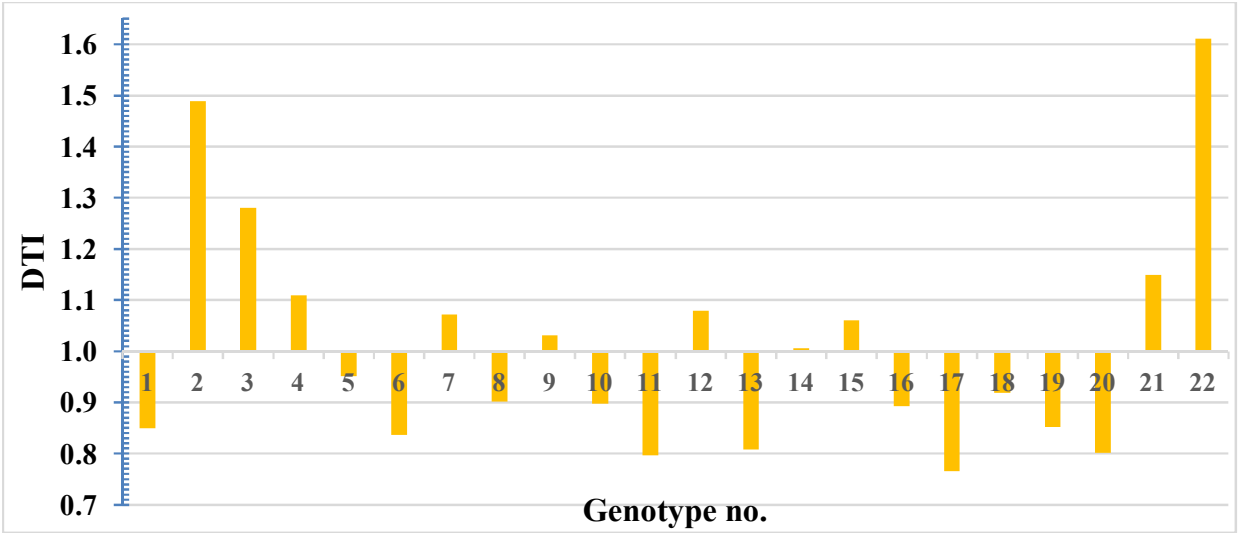

Fig. 1. Drought tolerance index (DTI) of genotypes from No.1 to No.22 under water stress (WS) across two seasons 
Table 4. Analysis of variance of RCBD design for grain quality traits of 22 wheat landraces and varieties evaluated under well watering (WW) and water stress (WS) in the 2016/2017 season

\begin{tabular}{|c|c|c|c|c|c|c|c|c|c|}
\hline \multirow[t]{2}{*}{ SV } & \multirow[t]{2}{*}{ df } & \multicolumn{8}{|c|}{ Mean squares } \\
\hline & & $\begin{array}{l}\text { WW } \\
\text { GPC }\end{array}$ & WS & $\begin{array}{l}\text { WW } \\
\text { GSC } \\
\end{array}$ & WS & $\begin{array}{l}\text { WW } \\
\text { GAC }\end{array}$ & WS & $\begin{array}{l}\text { WW } \\
\text { GMC }\end{array}$ & WS \\
\hline Genotypes & 21 & $13.53^{* \star}$ & $13.53^{* *}$ & $46.71^{\star *}$ & $46.72^{\star \star}$ & $1.03^{\star \star}$ & $1.04^{* \star}$ & $0.573^{\star \star}$ & $0.124 \mathrm{~ns}$ \\
\hline Error & 42 & 0.069 & 0.069 & 0.388 & 0.388 & 0.019 & 0.019 & 0.038 & 0.147 \\
\hline
\end{tabular}

Table 5. Drought tolerance index (DTI) of each accession across two seasons

\begin{tabular}{llllll}
\hline Genotype & Accession no. & DTI & Genotype & Accession no. & DTI \\
\hline G 1 & 9226 & 0.85 & G 12 & 9266 & 1.08 \\
G 2 & 9227 & 1.49 & G 13 & 9286 & 0.81 \\
G 3 & 9234 & 1.28 & G 14 & 9287 & 1.01 \\
G 4 & 9235 & 1.11 & G 15 & 9222 & 1.06 \\
G 5 & 9236 & 0.95 & G 16 & 9290 & 0.89 \\
G 6 & 9311 & 0.84 & $\mathbf{G ~ 1 7}$ & 9150 & 0.77 \\
G 7 & 9331 & 1.07 & $\mathbf{G ~ 1 8}$ & 9293 & 0.92 \\
G 8 & 9373 & 0.9 & $\mathbf{G ~ 1 9}$ & 9243 & 0.8 \\
G 9 & 9361 & 1.03 & $\mathbf{G ~ 2 0}$ & 9110 & 1.15 \\
G 10 & 9144 & 0.9 & $\mathbf{G ~ 2 1}$ & Yakora & 1.61 \\
G 11 & 9120 & 0.8 & $\mathbf{G ~ 2 2}$ & Sakha 64 \\
\hline
\end{tabular}

The drought-tolerant landraces were G2, G3, G4, G7, G9, G12 and G15 (Table 4, Fig. 1). The highest DTI (1.61) under the WS was exhibited by the local commercial wheat variety (Sakha 64) used as a check. The $2^{\text {nd }}$ and $3^{\text {rd }}$ highest genotypes in DTI (DTI=1.49 and 1.28) were the landraces G2 (Accession No. 9227) and G3 (Accession No. 9234), respectively. For productivity (grain yield) under WS, the three genotypes Sakha 64, the landraces G3 and G2 ranked $1^{\text {st }}, 2^{\text {nd, }}$ and $3^{\text {rd }}$, respectively, indicating that these three genotypes were the most DT and the highest yielding under drought stress environment. These three genotypes should be recommended to bread wheat breeding programs aiming at improving drought tolerance. On the contrary, the most DS genotype was the landrace G17 (Accession No 9150.); its grain yield under WS was the $4^{\text {th }}$ lowest. Several investigators reported genotypic variation in wheat drought tolerance [32-34].

\subsection{Trait Interrelationships}

Phenotypic correlation coefficients between all studied traits and DTI across the two seasons and across the two irrigation regimes were estimated (Table 6). DTI showed a strong positive and significant ( $p \leq 0.01)$ correlation coefficient with grain yield/plant ( $r=0.998)$, indicating that high grain yield is a perfect trait to select for high drought tolerance. This conclusion was previously reported by several investigators [41-44].

DTI showed a positive and significant correlation coefficient ( $p \leq 0.05$ or $p \leq 0.01$ ) with each of grains/spike (GPS), grain starch content (GSC) and grain moisture content (GMC) and a negative and significant correlation coefficient $(p \leq 0.05$ or $p \leq 0.01)$ with each of days to maturity (DTM), grain filling period (GFP), plant height $(\mathrm{PH})$ and grain protein content (GPC)(Table 6).

Grain yield/plant showed a perfect and positive association with DTI for combined data across WW and WS environments, explaining why the estimates of correlation coefficients between GYPP and other traits were very close to those between DTI and the same traits (Table 6). Grain yield/plant showed a positive and significant correlation coefficient ( $p \leq 0.05$ or $p \leq 0.01$ ) with each of grains/spike (GPS), grain starch content (GSC) and grain moisture content (GMC) and a negative and significant ( $p \leq 0.05$ or $p \leq 0.01$ ) correlation coefficient with each of grain filling period $(r=-0.488)$, plant height $(r=-0.495)$ and grain protein content $(r=-0.810)$. A negative correlation between the yield and protein content of wheat grain is also reported $[36,44,45]$. Implications to overcome the negative correlation between the percentage of grain protein and grain yield are reviewed [46]. 
Al-Naggar et al.; ARRB, 35(2): 25-40, 2020; Article no.ARRB.55937

Table 6. Simple correlation coefficients among studied traits of 22 wheat landraces and check cultivars across irrigation regimes

\begin{tabular}{|c|c|c|c|c|c|c|c|c|c|c|c|c|c|}
\hline Trait & DTA & DTM & GFP & $\mathbf{P H}$ & SPP & GPS & SPS & TGW & GYPP & GMC & GPC & GSC & GAC \\
\hline DTM & $0.659^{\text {*x }}$ & & & & & & & & & & & & \\
\hline GFP & 0.417 & $.941^{* \pi}$ & & & & & & & & & & & \\
\hline $\mathrm{PH}$ & -0.232 & -0.05 & 0.028 & & & & & & & & & & \\
\hline SPP & 0.306 & 0.264 & 0.154 & 0.046 & & & & & & & & & \\
\hline GPS & 0.085 & -0.317 & $-0.467^{\pi}$ & -0.096 & 0.042 & & & & & & & & \\
\hline SPS & $0.449^{\pi}$ & 0.083 & -0.038 & 0.13 & -0.023 & 0.366 & & & & & & & \\
\hline TGW & -0.355 & -0.31 & -0.228 & -0.083 & -0.144 & -0.142 & -0.295 & & & & & & \\
\hline GYPP & -0.042 & -0.401 & $-0.488^{*}$ & $-.495^{\star}$ & -0.136 & $0.491^{\star}$ & 0.217 & 0.174 & & & & & \\
\hline GMC & -0.128 & -0.299 & -0.355 & -0.206 & 0.282 & 0.385 & -0.028 & 0.14 & $0.497^{\pi}$ & & & & \\
\hline GPC & -0.09 & 0.388 & $0.502^{*}$ & 0.37 & 0.189 & -0.358 & -0.249 & $-0.504^{*}$ & $-0.810^{\star *}$ & -0.354 & & & \\
\hline GSC & -0.094 & -0.211 & -0.258 & -0.199 & -0.247 & 0.08 & -0.021 & 0.399 & $0.439^{*}$ & 0.342 & $-0.556^{\pi \pi}$ & & \\
\hline GAC & 0.346 & 0.326 & 0.295 & 0.016 & 0.346 & 0.009 & 0.037 & $-.509^{*}$ & -0.278 & 0.135 & 0.329 & $-0.512^{*}$ & \\
\hline DTI & -0.077 & $-0.439^{*}$ & $-0.523^{*}$ & $-0.485^{\star}$ & -0.139 & $0.491^{*}$ & 0.178 & 0.196 & $0.998^{\star *}$ & $0.501^{*}$ & $-0.808^{\star *}$ & $0.444^{\pi}$ & -0.304 \\
\hline
\end{tabular}


There is an increased pressure on plant breeders to improve grain protein and yield simultaneously. The feasibility of this simultaneous improvement, however, is a subject of controversy. Numerous genetic studies have shown the existence of major genes conferring enhanced grain protein concentration without adverse effects on yield $[18,47]$. Nevertheless, plant breeders' experience shows that simultaneous selection of grain protein concentration and yield is only occasionally successful at enhancing both characters [46].

While the observed variation in grain protein concentration in wheat is large (6.22\%) [48], much of this variation is environmental rather than genetic in origin. The protein concentration is determined by the genetic background, but also, to a large extent, by environmental factors such as nitrogen, water access, and temperature conditions. Consequently, selection for high grain protein concentration, especially in the early generations of a breeding program, is likely to be ineffective. Secondly, many studies have shown a negative correlation ( $r$ typically between -0.4 and -0.6 ) between grain protein concentration and overall yield [49].

Both processes, i.e. grain yield and grain protein content appear to be governed by different genetic factors [50]. For instance, results of extensive molecular studies, on wheat and maize revealed that different sets of genes (QTL regions) controlled various components of the two processes [51-53]. Hence, the appearance of the above mentioned negative relationship between grain yield and grain protein content in the examined landraces may be a genetic quandary.

A strong correlation was observed between grain filling period (GFP) and days to maturity (DTM) $(r=0.941)$, and between grain protein content (GPC) and each of DTI ( $r=-0.808)$ and GYPP $(r=-0.810)$ across all genotypes, irrigation regimes and seasons of study (Table 6).

The number of days to physiological maturity (DTM) had a positive and significant correlation coefficient with each of the days to anthesis (DTA), spikelets/spike (SPS) and grain filling period (GFP). Grain filling period had a positive and significant correlation with grain protein content and a negative and significant correlation with the number of grains/spike (GPS). Thousand-grain weight (TGW) showed a negative and significant correlation with each of grain protein content (GPC) and grain ash content (GAC).

A negative and significant correlation was found between GPC and grain starch content (GSC) and between GSC and GAC (Table 6). An inverse correlation between the protein content and B-type starch granules in wheat grains is reported [54]. The significant negative correlation between starch and grain protein content in the case of drought may indicate an important interaction between starch granules and proteins in determining the bread-making properties of flour [54].

The results of this study indicated that droughttolerant genotypes under WS as well as WW conditions were characterized by early DTM, short grain filling period, short plant height and less GPC \%, high grain yield/plant, and high grain moisture content (Table 6). This conclusion is in accordance with other investigators [41$43,55,56]$. High GYPP, GPS, GSC and GMC and low DTM, GFP, PH and GPC could be considered as selection criteria for drought tolerance in wheat. Significant correlations under drought stress were found between wheat grain yield and grain filling period, and the number of grains spike ${ }^{-1}[39,55]$.

Significant and negative $r$ value detected between GYPP of genotypes and plant height in the WS environment indicated that shorter plants of genotypes are of high yielding, under drought conditions. Shorter genotypes are higher-yielding than taller genotypes under both WW and water stress conditions [57]. Simane et al. [58] the number of grains per spike and grain mass has significant, positive, direct effects on grain yield under moisture stress conditions, as well as under well-watered conditions, when path analysis is applied [59]. These traits could be considered as selection criteria for drought tolerance in wheat if they prove high heritability and high predicted genetic advance from the selection. Drought tolerance as a trait can be assessed from any of these traits [59,60].

\subsection{Phenotypic and Genotypic Coefficients of Variation}

The estimates of phenotypic (PCV) and genotypic (GCV) coefficients of variation were shown (Table 7). In general, the estimates of PCV were a little higher than those of GCV, indicating that the effect of the environment on 
the studied traits was low. Both PCV and GCV estimates were higher under WW than corresponding estimates under WS conditions for most studied traits. These results are in agreement with a group of investigators [18,61], who reported higher genotypic and phenotypic variation under WW conditions than under WS conditions. On the contrary, the PCV and GCV estimates were higher under WS than corresponding estimates under WW conditions for DTM, GFP, TGW and GSC.

The highest estimates of PCV and GCV were exhibited by grain ash content followed by grain yieldplant ${ }^{-1}$, while the lowest ones were shown by days to anthesis, grain moisture content and days to maturity (Table 7). Selection would be more effective when the coefficient of variation is high, but the opposite is true when the coefficient of variation is low. Thus, based on the results of our experiment, selection would be more efficient among landraces for high grain yield, high grain protein content and the number of grain/spike, especially under well-watered conditions.

\subsection{Heritability and Expected Genetic Advance from the Selection}

Estimates of heritability in the broad sense $\left(\mathrm{h}^{2}{ }_{\mathrm{b}}\right)$ and expected genetic advance from selection as a percentage of the mean (GA\%) for landraces and check cultivars under WW and WS conditions were shown (Table 8).

Table 7. Phenotypic (PCV) and genotypic (GCV) coefficients of variation for studied traits under well watering and water stress conditions across two seasons

\begin{tabular}{|c|c|c|c|c|}
\hline \multirow[t]{2}{*}{ Traits } & \multicolumn{2}{|c|}{ WW } & \multicolumn{2}{|c|}{ WS } \\
\hline & PCV\% & GCV\% & PCV\% & GCV\% \\
\hline DTA & 2.86 & 2.75 & 1.62 & 1.37 \\
\hline DTM & 6.21 & 5.76 & 9.72 & 9.11 \\
\hline GFP & 17.41 & 15.91 & 25.67 & 22.22 \\
\hline PH & 19.27 & 16.50 & 16.13 & 13.88 \\
\hline SPP & 18.23 & 12.82 & 14.03 & 12.12 \\
\hline GPS & 25.33 & 23.33 & 19.29 & 15.92 \\
\hline SPS & 14.31 & 12.78 & 12.93 & 9.90 \\
\hline TGW & 11.38 & 5.87 & 17.32 & 14.95 \\
\hline GYPP & 34.78 & 30.75 & 32.55 & 28.00 \\
\hline GMC & 5.93 & 5.86 & 3.70 & 3.27 \\
\hline GPC & 25.77 & 25.75 & 22.61 & 22.59 \\
\hline GSC & 11.10 & 11.08 & 11.47 & 11.45 \\
\hline GAC & 61.64 & 60.02 & 51.96 & 51.80 \\
\hline
\end{tabular}

Table 8. Heritability in broad-sense $\left(\mathrm{h}_{\mathrm{b}}^{2}\right)$ and genetic advance from selection (GA\%) for studied traits under well watering (WW) and water stress (WS) conditions across two seasons

\begin{tabular}{|c|c|c|c|c|}
\hline \multirow[t]{2}{*}{ Traits } & \multicolumn{2}{|c|}{ WW } & \multicolumn{2}{|c|}{ WS } \\
\hline & $\mathbf{h}_{\mathrm{b}}^{2}$ & GA\% & $\mathbf{h}_{\mathrm{b}}^{2}$ & GA\% \\
\hline DTA & 92.49 & 4.66 & 68.71 & 1.96 \\
\hline DTM & 86.14 & 9.41 & 87.95 & 15.04 \\
\hline GFP & 83.58 & 30.32 & 74.92 & 33.85 \\
\hline $\mathrm{PH}$ & 73.38 & 24.88 & 74.06 & 21.02 \\
\hline SPP & 83.74 & 20.65 & 74.52 & 18.41 \\
\hline GPS & 84.84 & 37.82 & 68.05 & 23.11 \\
\hline SPS & 79.76 & 20.08 & 72.71 & 14.86 \\
\hline TGW & 52.15 & 12.93 & 74.45 & 22.70 \\
\hline GYPP & 78.18 & 47.86 & 73.99 & 42.39 \\
\hline GPC & 99.83 & 45.27 & 99.83 & 39.72 \\
\hline GSC & 99.72 & 19.48 & 99.72 & 20.13 \\
\hline GAC & 94.81 & 97.60 & 99.40 & 90.89 \\
\hline GMC & 67.62 & 11.62 & 77.93 & 5.08 \\
\hline
\end{tabular}


Estimates of heritability were higher under well watering than those under water stress for six traits (DTA, GFP, SPP, GPS, SPS, and GYPP), were higher under water stress than those under well watering for five traits (DTM, PH, TWG, GAC, and GMC), and were approximately similar under both environments for two traits (grain protein content and grain starch content)-(Table 8). Estimates of genetic advance were higher under WW than WS conditions for 9 out of 13 studied traits (DTA, PH, SPP, GPS, SPS, GYPP, GPC, GAC, and GMC). On the contrary, estimates of genetic advance were higher under WS than under WW for DTM, GFP GSC, and TGW traits. Thus, in general, estimates of $h^{2}{ }_{b}$ and GA were higher under WW than under WS conditions for the majority of studied traits. Thus, it is better to practice selection for these traits under WW conditions to obtain higher values of selection gain $[31,44]$.

Since the efficiency of selection would depend upon the magnitude of heritable variability, higher heritability accompanied by high expected genetic advance for the traits under study should be quite valuable. It is obvious from the results of this study (Table 8), that the traits having high heritability accompanied by high values of expected genetic advance were grain filling period, grains/spike, grain yield/plant, spikes/plant, grain protein content, grain starch content, plant height and grain ash content under both well watering and water stress conditions and days to maturity under water stress. Such traits are therefore controlled by additive types of gene action, i.e. the heritable components of genetic variance, which are amenable to an efficient selection $[31,44,62]$.

Two contrasting strategies are applied to identify genotypes that will be high yielding under abiotic stress: Genotypes may be evaluated under (i) the conditions in which they will ultimately be produced, namely a certain type of stress, to minimize genotype $x$ environment interaction, but it may result in low heritability [63]; (ii) Genotypes may be evaluated under optimum conditions maximizing heritability, but perhaps encountering problems with high genotype $x$ environment interactions [64]. A third alternative, currently used at CIMMYT, which is simultaneous evaluation under near optimum and stress conditions, with the selection of those genotypes that perform well in both environments [65]. However, the ultimate evaluation must be performed in the target environment prior to recommendation for a cultivar for commercial production.
Two groups of researchers reported two contrasting conclusions; the first group of investigators reported that heritability and expected genetic advance is higher under stress than non-stress conditions, and that selection should be practiced in the target (stressed) environment to obtain higher genetic advance $[28,43,66,67]$. The second group of researchers found that heritability and GA from selection for grain yield are higher under non-stress than those under stress $[68,69]$. Our results for the majority of studied traits, especially for grain yield and its components (Table 8) were in agreement with the second group, but for the rest of the studied traits (DTM, TWG and GMC) our results were in agreement with the first group.

Based on the correlation coefficients ( $r$ ) between studied traits and DTI and their corresponding estimates of broad-sense heritability, it is evident that the best secondary trait for drought tolerance in our study is GYPP, followed by GPS, GFP, GSC, GPC, PH and DTM, since they showed high $(r)$, high $\left(h^{2}{ }_{b}\right)$ and high (GA)estimates.

\section{CONCLUSIONS}

Landraces can be considered as sources of putatively lost variability and may provide new genes or alleles, which could be introgressed into modern varieties by hybridization. Our study recommends that landrace G17 (the highest in protein content, $20.87 \%$ ) could be crossed to one of the highest yielding genotypes (Sakha 64 cultivaror landrace G2 or G3) to select in their segregating generations some transgressive segregants that accumulate genes of high GYPP and high GPC. Our results concluded that drought-tolerant genotypes conditions were characterized by high GYPP, early DTM, short GFP, and short $\mathrm{PH}$. In general, estimates of heritability $\left(h^{2}{ }_{b}\right)$ and genetic advance $(G A)$ were higher under well-watered conditions than under water deficit conditions for DTA, PH, SPP, GPS, SPS, GYPP, GPC, GAC and GMC traits, thus, it is better to practice selection in our material for these traits under well-watering conditions to obtain high values of selection gain. On the contrary, estimates of genetic advance were higher under WS than under WW for DTM, GFP, GSC, and TGW traits, and thus it is better to practice selection in our material for these traits under deficit irrigation conditions. The best secondary trait for DT in our study is GYPP, followed by GPS, GFP, GSC, GPC, PH and DTM, since they showed a high correlation coefficient $(r)$ with DT, high $\left(h_{b}^{2}\right)$ and high (GA) estimates. 
This information could help future breeding programs in selection for improving drought tolerance of wheat.

\section{COMPETING INTERESTS}

Authors have declared that no competing interests exist.

\section{REFERENCES}

1. Gupta PK, Langridge P, Mir RR. Markerassisted wheat breeding: Present status and future possibilities. Molecular Breedin. 2010;26(2):145-161.

2. Ortiz R, Sayre KD, Govaerts B, Gupta R, Subbarao GV, Ban T, Hodson D, Dixon $\mathrm{JM}$, Ortiz-Monasterio JI, Reynolds M. Climate change: Can wheat beat the heat? Agriculture, Ecosystem \& Environment. 2008;126:46-58.

3. FAOSTAT. Food and Agriculture Organization, Statistical Division; 2009.

Available:http://www.fao.org/faostat/en/\#da ta/QC

(Accessed on 20 November 2019)

4. Burton GW, Devane DE. Estimating heritability in tall fescue (Festuca arundinacea) from replicated clonal material. Agronomy Journal. 1953;45(10): 478-481.

5. Grassini P, Eskridge KM, Cassman KG. Distinguishing between yield advances and yield plateaus in historical crop production trends. Nature Communications. 2013;4.

DOI: 10.1038/ncomms3918

6. Zeven AC. Landraces: A review of definitions and classifications. Euphytica. 1998;104:127-139.

7. Peng JH, Sun D, Nevo E. Domestication evolution, genetics and genomics in wheat. Molecular Breeding. 2011;28:281-301.

8. Fuller DQ. Contrasting patterns in crop domestication and domestication rates: Recent archaeobotanical insights from the old world. Annals of Botany. 2007;100: 903-924.

9. Cockram J, Norris C, O'Sullivan DM. PCRbased markers diagnostic for spring and winter seasonal growth habit in barley. Crop Science. 2009;49:403-410.

10. Zaharieva M, Ayana NG, Al Hakimi A, Misra SC, Monneveux P. Cultivated emmer wheat (Triticum diccocum Schrank), an old crop with a promising future: A review. Genet Resour Crop Evol. 2010;57:937-62.
Available:https://doi.org/10.1007/s10722010-9572-6

11. Vasconcelos FS, Vasconcelo ES, Balan MG, Silvério L. Desenvolvimento eprodutividade de quinoa semeada em diferentes datas no período safrinha. Ciência Agronômica. 2012;43(3):510-515.

12. Cruz CD, Regazzi AJ, Carneiro PC. Modelos biométricos aplicados ao melhoramento genético (4a Ed.). Viçosa, MG: UFV; 2012.

13. Banziger $M$, Edmeades $G O$, Lafitte $H R$. Physiological mechanisms contributing to the increased $\mathrm{N}$ stress tolerance of tropical maize selected for drought tolerance. Field Crop Res. 2002;75:223-233.

14. Manette AS, Johnson RC, Carver BF, Mornhinweg DW. Water relation in winter wheat as drought resistance indicators. Crop Sci. 1988;28:526-531.

15. Gautam RK, Sethi GS. Character association in Secale cereal L. introgressed bread wheat under irrigated and water stress conditions. Indian J. of Gen. and Plant Breed. 2002;62:69-70.

16. Golabady M, Arzani A. Study of genetic variation and factor analysis of agronomic traits in durum wheat. J. Sci. and Techn. Agric. and Natural Resources. 2003;7(1): 115-127.

17. Al-Naggar AMM, Shehab-El-Deen MT. Predicted and actual gain from selection for early maturing and high yielding wheat genotypes under water stress conditions. Egypt. J. Plant Breed. 2012;16(3):73-92.

18. Al-Naggar AM, Atta MM, Shaheen AM, ELAzab KF. Gamma rays and EMS induced drought-tolerant mutants in bread wheat. Egypt. J. Plant Breed. 2007;11(3):135165.

19. Zafarnaderi N, Aharizad S, Mohammadi SA. Relationship between grain yield and related agronomic traits in bread wheat recombinant inbred lines under water deficit condition. Annals of Biological Research. 2013;4(4):7-11.

20. Fageria NK. Maximizing crop yields. Dekker. New York. 1992;423.

21. Steel RGD, Torrie JH, Dickey D. Principles and procedure of statistics. A Biometrical Approach $3^{\text {rd }}$ Ed. McGraw Hill Book Co. Inc., New York. 1997;352-358.

22. Hallauer AR, Miranda JB. Quantitative genetics in maize breeding. $2^{\text {nd }} \mathrm{Ed}$. lowa State Univ. Press, Ames., IA., USA. 1988;237. 
23. Singh $P$, Narayanan SS. Biometrical techniques in plant breeding. Kalayani Publishers, New Delhi, India; 2000.

24. Newton AC, Akar T, Baresel JP, Bebeli PJ, Bettencourt $\mathrm{E}$, Bladenopoulos $\mathrm{KV}$, Czembor JH, Fasoula DA, Katsiotis A, Koutis K, Koitsuka-Sotiriou M, Kovacs G, Larsson $\mathrm{H}$, de Carvalho MAAP, Rubiales D, Russell J, Tmm DS, Vaz Patto MC. Cereal landraces for sustainable agriculture. A review. Agron Sustain Dev. 2010;30(2):237-69.

25. Galili G, Galili S, Lewinsohn E, Tadmor Y. Genetic, molecular and genomic approaches to improve the value of plant foods and feeds. CRC Crit Rev. Plant Sci. 2002;21(3):167-204.

26. Lopes MS, Dreisigacker S, Pena J, Sukumaran S, Reynolds M. Genetic characterization of the Wheat Association Mapping Initiative (WAMI) panel for dissection of complex traits in spring wheat. Theoretical and Applied Genetics. 2015;128:453-464.

27. Kheiralla KA, Ismail AA, El-Nagar GR. Drought tolerance and stability of some spring wheat cultivars. Assiut J. of Agric. Sci. 1997;28(1):75-88.

28. Al-Naggar AMM, Hussein HAA, Hussien EHA, Sabry SRS, Kh. IM. Gad. Genetic diversity and bulked segregant analysis for earliness in bread wheat. Arab J. of Biotech. 2010;13(2):157- 172.

29. Sharma HP, Bhargava SC. Relative sensitivity of wheat genotypes under moisture stress conditions. Annals of Biology Ludhiana. 1996;12(1):39-42.

30. Day $A D$, Intalap $S$. Some effects of soil moisture stress on the growth of wheat (Triticum aestivum L. Thell). Agron. J. 1970;62:27-29.

31. Al-Naggar AMM, Sabry SRS, Atta MMM, Ola M. Abd El-Aleem. Differential responses of bread wheat doubled haploids to elevated levels of salinity at germination and seedling stages. Egypt. J. Plant Breed. 2014;18(3):429-452.

32. Barraclough PB, Howartha JR, Jonesa J, Lopez-Bellido R, Parmara S, Shepherda Hawkesforda MJ. Nitrogen efficiency of wheat: Genotypic and environmental variation and prospects for improvement. Eur. J. Agron. 2010;33:1-11.

33. Al-Naggar AMM, Kh F, Al-Azab SES, Sobieh, Atta MMM. Use of gamma rays and hybridization to create new drought tolerant wheat genotypes. International
Journal of Plant \& Soil Science. 2015;5(5):282-299.

34. Foulkes J, Holdsworth M, Kerr S, Kightly S, Barraclough P, Hawkesford M, Shewry S. Study of the scope for the application of crop genomics and breeding to increase nitrogen economy within cereal and rapeseed based food chains. Final Report for Project AR0714. Defra, London; 2006.

35. Clarke M, Towenley-Smith T, McCaig T. Growth analysis of spring wheat cultivars of varying drought resistance. Crop Sci. 1984;24:537-541.

36. Fowler D, Brydon J, Darroch BA, Entz MH, Johnston AM. Environment and genotype influence on grain protein concentration of wheat and rye. Agron J. 1990;82:666664.

37. Flagella Z, Giuliani MM, Giuzio L, Volpi C, Masci $S$. Influence of water deficit on durum wheat storage protein composition and technological quality. Eur. J. Agron. 2010;33:197-207.

38. Rharrabti Y, Villegas D, Royo C, MartosN'ũ nez, V, Garc'ia del Moral LF. Durum wheat quality in Mediterranean environments. II. Influence of climatic variables and relationships between quality parameters. Field Crops Res. 2003;80: 133-140.

39. Garrido-Lestache EL, Lopez-Bellido RJ, Lopez-Bellido L. Durum wheat quality under Mediterranean conditions as affected by $\mathrm{N}$ rate, timing and splitting, $\mathrm{N}$ form and $\mathrm{S}$ fertilization. Eur. J. Agron. 2005;23:265-278.

40. Barnabas B, J"ager K, Feher A. The effect of drought and heat stress on reproductive processes in cereals. Plant Cell Environ. 2008;31:11-38.

41. Banziger M, Edmeades GO, Lafitte HR. Physiological mechanisms contributing to the increased $\mathrm{N}$ stress tolerance of tropical maize selected for drought tolerance. Field Crop Res. 2002;75:223-233.

42. Al-Naggar AMM, Soliman SM, Hashimi MN. Tolerance to drought at flowering stage of 28 maize hybrids and populations. Egypt. J. Plant Breed. 2011;15(1):69-87.

43. Al-Naggar AMM, Abdalla AMA, Gohar AMA, Hafez EHM. Heritability, genetic advance and correlations in 254 maize doubled haploid lines $\times$ tester crosses under drought conditions. Archives of Current Research International. 2016;6(1): 1-15. 
44. Al-Naggar AMM, Shabana R, Abd-ElAleem MM, El-Rashidy Z. Mode of inheritance of Low-N tolerance adaptive traits in wheat (Triticum aestivum L.) under contrasting nitrogen environments. Spanish Journal of Agricultural Research. 2017;15(2):1-11.

45. Loffler CM, Busch RH. Selection for grain protein, grain yield and nitrogen partitioning efficiency in hard red spring wheat. Crop Sci. 1982;22:591-595.

46. Feil B. The inverse yield-protein relationship in cereals: Possibilities and limitation for genetically improving the grain protein yield. Trends in Agronomy. 1997;1:103-119.

47. Stuber CW, Johnson VA, Schmidt JW. Grain protein content and its relationship to other plant and seed characters in the parents and progeny of a cross of Triticum aestivum L. Crop Sci. 1962;2:506-508.

48. Johnson VA, Lay CL. Genetic improvement of plant protein. J. Agric. Food Chem. 1974;22:558-566.

49. Johnson VA, Mattern PJ, Peterson CJ, Kuhr SL. Improvement of wheat protein by traditional breeding and genetic techniques. Cereal Chem. 1985;62:350355.

50. Gallais A, Hirel B. An approach to the genetics of nitrogen use efficiency in maize. J. Exp. Bot. 2004;55:295-306.

51. Bertin P, Gallais A. Physiological and genetic basis of nitrogen use efficiency in maize. I. Agrophysiological results. Maydica. 2000;45:53-66.

52. Habash DZ, Bernard S, Schondelmaier J, Weyen J, Quarrie SA. The genetics of nitrogen use in hexaploid wheat: $N$ utilisation, development and yield. Theor. Appl. Genet. 2007;114:403-19.

53. Laperche A, Brancourt-Hulmel M, Heumez E, Gardet O, Hanocq E, et al. Using genotype $\mathrm{x}$ nitrogen interaction variables to evaluate the QTL involved in wheat tolerance to nitrogen constraints. Theor. Appl. Genet. 2007;115:399-415.

54. Balla K, Rakszegi M, Li Z, Bekes F, Bencze S, Veisz O. Quality of winter wheat in relation to heat and drought shock after anthesis. Agric. Res. Inst. Hung. Acad. Sci. 2011;29:117-128.

55. Bolaños J, Edmeades GO, Martinez L. Eight cycles of selection for drought tolerance in lowland tropical maize. III. Responses in drought-adaptive physiological and morphological traits. Field Crops Res. 1993;31:269-286.

56. Bolaños J, Edmeades GO. The importance of the anthesis-silking interval in breeding for drought tolerance in tropical maize. Field Crops Res. 1996;48(1):65-80.

57. Sofiatti V, Cargnin A, Silva LVBD, Galvao JCC. Maize population increase and reduced spacing between plant rows. J. Sci. Rural. 2007;12(1):131-139.

58. Simane B, Struik PC, Nachit MM, Peacock JM. Ontogenetic analysis of yield components and yield stability of durum wheat in water-limited environments. Euphytica. 1993;71(3):211-219.

59. Fernandez GCJ. Effective selection criteria for assessing stress tolerance. In Proceedings of the International Symposium on Adaptation of Vegetables and Other Food Crops in Temperature and Water Stress, Taibei, Taiwan. 1992;13-16.

60. Sallam A, Hamed E-S, Hashad M, Omara $M$. Inheritance of stem diameter and its relationship to heat and drought tolerance in wheat (Triticum aestivum L.). J. Plant Breed. Crop Sci. 2014;6:11-23.

61. Chowdhury RK. Induced quantitative variation in wheat. Wheat Inform. Services. 1982;54:27-31.

62. Al-Naggar AMM, Shafik MM, Elsheikh MO. Heritability and correlations for agronomic and physiologic traits of maize under deficit irrigation at two growth stages. Asian Journal of Biochemistry, Genetics and Molecular Biology. 2018;1(3):1-17.

63. Ceccarelli S. Wide adaptation: How wide? Euphytica. 1989;40:197-205.

64. Braun $\mathrm{H}$, Pfeiffer WH, Pollmer WG. Environments for selecting widely adapted spring wheat. Crop Sci. 1992;32:14201427.

65. Calhoun DS, Gebeyehu G, Mirranda A, Rajaram S, Ginkel VM. Choosing evaluation environments to increase wheat grain yield under drought conditions. Crop Sci. 1994;34:673-678.

66. Blum A. Breeding crop varieties for stress environments. Crit. Rev. Plant Sci. 1988;2: 199-238.

67. Al-Naggar AMM, Shabana R, Mahmoud A. A. Abdel El-Azeem MEM, Shaboon SAM. Recurrent selection for drought tolerance improves maize productivity under low-N conditions. Egypt. J. Plant Breed. 2009;13: 53-70. 
68. Rosielle AA, Hamblin J. Theoretical aspects of selection for yield in stress and non-stress environments. Crop Sci. 1981;21:943-946.
69. Shabana R, Bailey T, Frey KJ. Production traits of oats selected under low; medium and high productivity. Crop Sci. 1980;20: 739-744.

(C) 2020 Al-Naggar et al.; This is an Open Access article distributed under the terms of the Creative Commons Attribution License (http://creativecommons.org/licenses/by/4.0), which permits unrestricted use, distribution, and reproduction in any medium, provided the original work is properly cited.

Peer-review history:

The peer review history for this paper can be accessed here: http://www.sdiarticle4.com/review-history/55937 